\title{
Article \\ Experimental Investigation on the Performance and Emission Characteristics of a Compression Ignition Engine Using Waste-Based Tire Pyrolysis Fuel and Diesel Fuel Blends
}

\author{
István Péter Kondor ${ }^{1} * \mathbb{E}$, Máté Zöldy ${ }^{2}$ and Dénes Mihály ${ }^{1}$ \\ 1 Department of Vehicle Technologies, John von Neumann University, H-6000 Kecskemét, Hungary; \\ mihaly.denes.work@gmail.com \\ 2 Department of Automotive Technologies, Budapest University of Technology and Economics, \\ H-1521 Budapest, Hungary; zoldy.mate@kjk.bme.hu \\ * Correspondence: kondor.peter@kjk.bme.hu
}

check for updates

Citation: Kondor, I.P.; Zöldy, M.; Mihály, D. Experimental

Investigation on the Performance and

Emission Characteristics of a

Compression Ignition Engine Using Waste-Based Tire Pyrolysis Fuel and Diesel Fuel Blends. Energies 2021, 14, 7903. https://doi.org/10.3390/ en14237903

Academic Editor: Piotr Folęga

Received: 19 October 2021

Accepted: 15 November 2021

Published: 25 November 2021

Publisher's Note: MDPI stays neutral with regard to jurisdictional claims in published maps and institutional affiliations.

Copyright: (c) 2021 by the authors. Licensee MDPI, Basel, Switzerland. This article is an open access article distributed under the terms and conditions of the Creative Commons Attribution (CC BY) license (https:/ / creativecommons.org/licenses/by/ $4.0 /)$.

\begin{abstract}
Due to the world's growing population, the size of areas intended for food production in many countries of the world can only be achieved through severe environmental damage and deforestation, which has many other detrimental consequences in addition to accelerating global warming. By replacing the bio-content of fuels with other alternative fuels, land that is used for energy crops can also be used to grow food, thus mitigating the damaging effects of deforestation. Waste-based tire pyrolysis oil (TPO) can be a promising solution to replace the bio-proportion of diesel fuel. Since it is made from waste tires, it is also an optimal solution for recycling waste. This research shows the effect of different low-volume-percent tire pyrolyzed oil blended with diesel on the performance, fuel consumption, and emissions on a Mitsubishi S4S-DT industrial diesel engine. Four different premixed ratios of TPO were investigated $(2.5 \%, 5 \%, 7.5 \%$ and $10 \%)$ as well as pyrolysis oil and $100 \%$ diesel oil; however, the following studies will only include the data from the pure diesel and the $10 \%$ TPO measurements. The experimental investigations were in an AVL electric dynamometer, the soot measurements were in an AVL (Anstalt für Verbrennungskraftmaschinen List) Micro soot sensor (MSS), and the emission measurements were in a AVL Furier-transform infrared spectroscopy (FTIR) taken. The scope of research was to investigate the effect of low volume percentage TPO on performance and emissions on a light-duty diesel engine.
\end{abstract}

Keywords: waste based fuel; tire pyrolysis oil; emissions; diesel engine

\section{Introduction}

Growing energy consumption leads to a constant shortage and increased fossil fuel usage in this time and age. To fight against this, alternative fuel sources have to be found and applied. There are numerous ways to produce biofuels, and tire pyrolysis is a promising technology that is not only able to supply biofuel, but it can also help humanity clean the environment. In Europe, the yearly tire waste output is over 3 million tonnes and over 17 million tonnes worldwide [1]. It is also an increasing problem since most of the waste rubber ends up in landfills. Pyrolysis is a process where organic material in the absence of oxygen is heated to a temperature at which it decomposes. The word pyrolysis is made up of two words: "Pyro", which means fire, and "lysis", which means separating. The tire pyrolysis process begins with cleaning the rubber, shredding the waste tires into small pieces, and then loading them into a rotary kiln. When there is sufficient material in the kiln, it is closed, and the pyrolysis begins. The chamber is heated up to 350-800 ${ }^{\circ} \mathrm{C}$ gradually [2]. The optimum temperatures, however, range from 500 to $600{ }^{\circ} \mathrm{C}$. The temperatures can be further increased for different results [3]. During the process, the tires chemically decompose and evaporate. From the vapor pyrolysis, oil and pyrolysis gas is made [4]. The remaining material in the chamber is pyrolysis carbon black, metal, and kevlar. 
The tire pyrolysis oil is a dark-colored, strong-scented fluid. Its viscosity is similar to diesel, but its density is higher. Furthermore, the fluid's wetting ability is similar to diesel's. TPO's cetane number is lower, and its heating value is higher [5]. During the experiments, an industrial engine was used. It was chosen due to its excellent durability and robust design [6]. It is still used to this day as a powerplant for multiple purposes. This engine was also chosen because it can be used as a constant speed unit, just like the internal combustion engines in large powerplant facilities [7].

\section{Methodology}

The experiments were conducted on a Mitsubishi S4S-DT medium-duty engine and on AVL-branded measuring devices. The measured parameters were the engine's torque, power, fuel consumption, exhaust gas emission, and particle concentration. The engine laboratory's schematic can be seen in Figure 1. The experiments began with a pure diesel test. These data were used for later comparisons. The following experiments were $2.5 \mathrm{vol} \%$, $5 \mathrm{vol} \%, 7.5 \mathrm{vol} \%$, and $10 \mathrm{vol} \%$ pyrolysis diesel content, although they were not compared, due to the differences being minimal. The properties of the tire pyrolysis oil can be found in Table 1. The mixtures tested had no specific data sheet, since they were not measured individually in a laboratory.

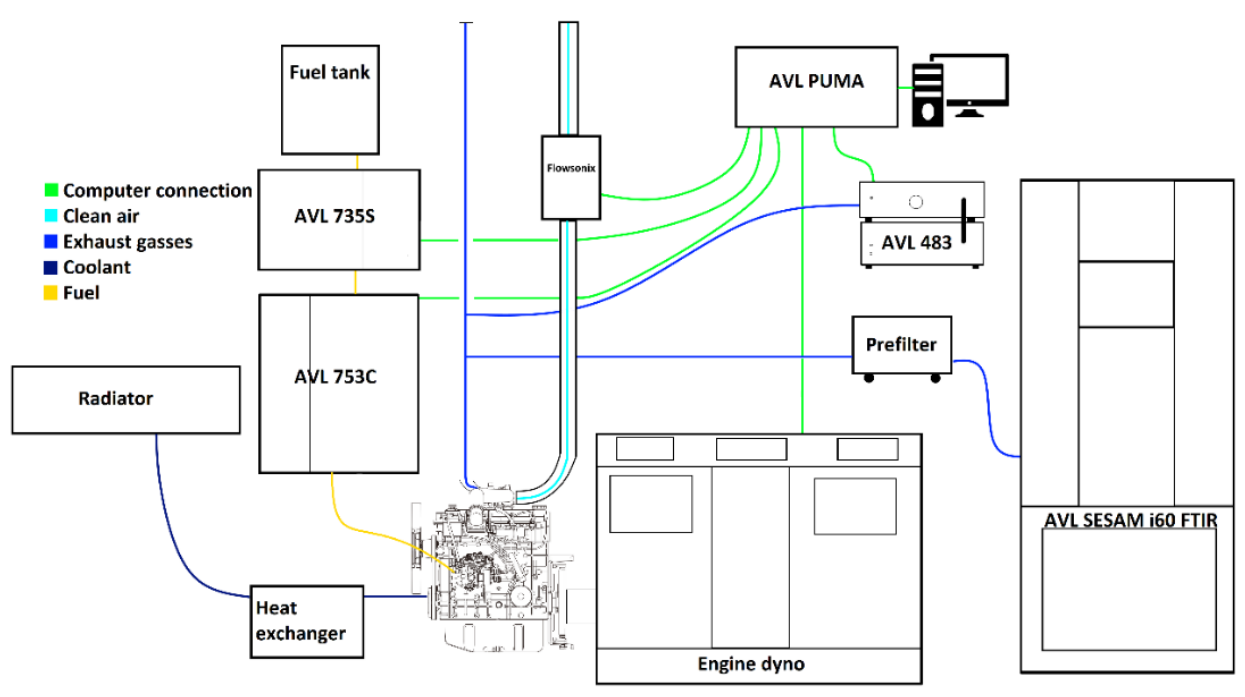

Figure 1. Shematic diagram of experimental setup.

Table 1. Main parameters of TPO and diesel fuels.

\begin{tabular}{cccc}
\hline & TPO & Diesel & Standard \\
\hline Cetane & $<30$ & $\geq 51.0$ & MSZ EN ISO 5165 \\
Sulfur $[\mathrm{mg} / \mathrm{kg}]$ & $\leq 10$ & $\leq 10$ & MSZ EN ISO 20846 \\
Water $(\mathrm{ppm})[\mathrm{mg} / \mathrm{kg}]$ & 1804 & $\leq 200$ & MSZ EN ISO 12937 \\
Pensky-Martens flashpoint & $<24$ & $>55$ & MSZ EN 2719 \\
Caloric Value $[\mathrm{MJ} / \mathrm{kg}]$ & 40.8 & 42.7 & MSZ EN ISO 6245 \\
Ash $[\% / \mathrm{m} / \mathrm{m}]$ & 0.005 & $\leq 0.01$ & MSZ EN ISO 3104 \\
Viscosity $\left[\mathrm{mm}^{2} / \mathrm{s}\right]$ & 4.443 & $2.00-4.50$ & MSZ EN 12662 \\
Mechanical inpurities $[\mathrm{mg} / \mathrm{kg}]$ & $0.027-0.16$ & $\leq 24$ & \\
Density $\left[\mathrm{kg} / \mathrm{m}^{3}\right]$ & 926.1 & $\leq .83$ & EN ISO 10370 \\
Coke residue $[\% / \mathrm{m} / \mathrm{m}]$ & 0.6 & $\leq 50.30$ & MSZ EN 116 \\
Cold filter plugging point $(\mathrm{CFPP})$ & & $<8.0$ & MSZ EN 12916 \\
Policyclic carbohidrates & $22-35$ & &
\end{tabular}




\subsection{Measured Engine Operating Points}

Every measuring point was examined three times to eliminate measuring errors. The measuring points were selected based on the engine characteristics. The measuring points which were measured are shown in Table 2. The engine parameters can be seen in Table 3 .

Table 2. Engine operating points.

\begin{tabular}{cccccc}
\hline Speed & \multicolumn{5}{c}{ Alpha } \\
\hline $1900 \mathrm{RPM}$ & $40 \%$ & $50 \%$ & $60 \%$ & $80 \%$ & $100 \%$ \\
$2200 \mathrm{RPM}$ & & & & $80 \%$ & $100 \%$ \\
\hline
\end{tabular}

Table 3. Engine specification.

\begin{tabular}{cc}
\hline Parameters & Details \\
\hline Engine series & Mitsubishi S4S-DT \\
Engine type & 4 stroke diesel \\
Cylinder layout & Inline \\
Number of cylinders & 4 \\
Displacement & $3331 \mathrm{~cm}^{3}$ \\
Stroke $\times$ bore $(\mathrm{mm})$ & $120 \times 94$ \\
Aspiration & Turbocharged \\
Dry weight & $250 \mathrm{~kg}$ \\
Fuel injection & Direct injection \\
Fuelpump type & Rotary pump \\
Maximum power output & $70 \mathrm{~kW}$ \\
Maximum engine speed & $25001 / \mathrm{min}$ \\
\hline
\end{tabular}

\subsection{Exhaust Gas and Particulate Matter Measurement Method}

\subsubsection{Exhaust Gas Analyzer}

Exhaust gas analysis is carried out by an Fourier transform infrared (FTIR) spectrometer (Model-AMA i60). The instrument measures the concentration of carbon monoxide $(\mathrm{CO}$ in $\% \mathrm{ppm})$ carbon dioxide $\left(\mathrm{CO}_{2}\right)$, hydrocarbons $(\mathrm{HC})$, and total nitorgen oxides $\left(\mathrm{NO}_{\mathrm{x}}\right)$. The FTIR measuring principle is a measurement with infrared (IR) light [8]. The principle of FTIR is that the gas to be analyzed is led through a cuvette with an IR light source at one end that is sending out scattered IR light, and a modulator that "cuts" the infrared light into different wavelengths [9]. A detector measures the amount of IR light to pass through the cuvette at the other end of the cuvette. Fourier transformation mathematics is used by data processing to turn the measured absorption values into gas concentrations for the analyzed gases [10]. The schematic diagram of the measuring principle of an FTIR is shown in Figure 2.

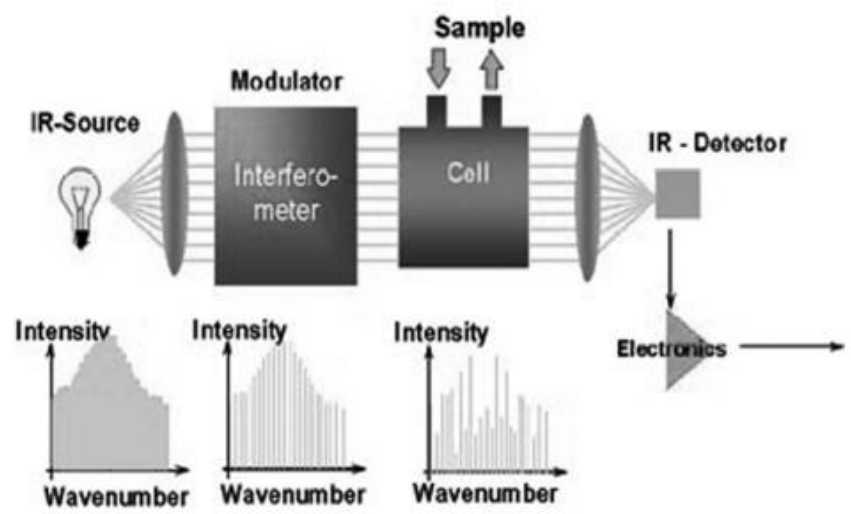

Figure 2. Schematic diagram of measuring principle of an FTIR [11]. 
The AVL SESAM FTIR uses Michelson Interferometer with two mirrors, a fixed one and a movable one. The wideband infrared radiation of the light source is split into two beams by a beamsplitter. One of the beams hits the fixed mirror the other one hits the movable mirror [11]. They are subsequently added to one beam. With the interference effects varying, erasement and amplification of single wavelengths occur depending on the position of the movable mirror [12]. This modified infrared light is transferred into the gas cell. At each movement of the mirror, an interferogram is registered by the infrared detector [13]. The spectrometer bench setup is shown in Figure 3.
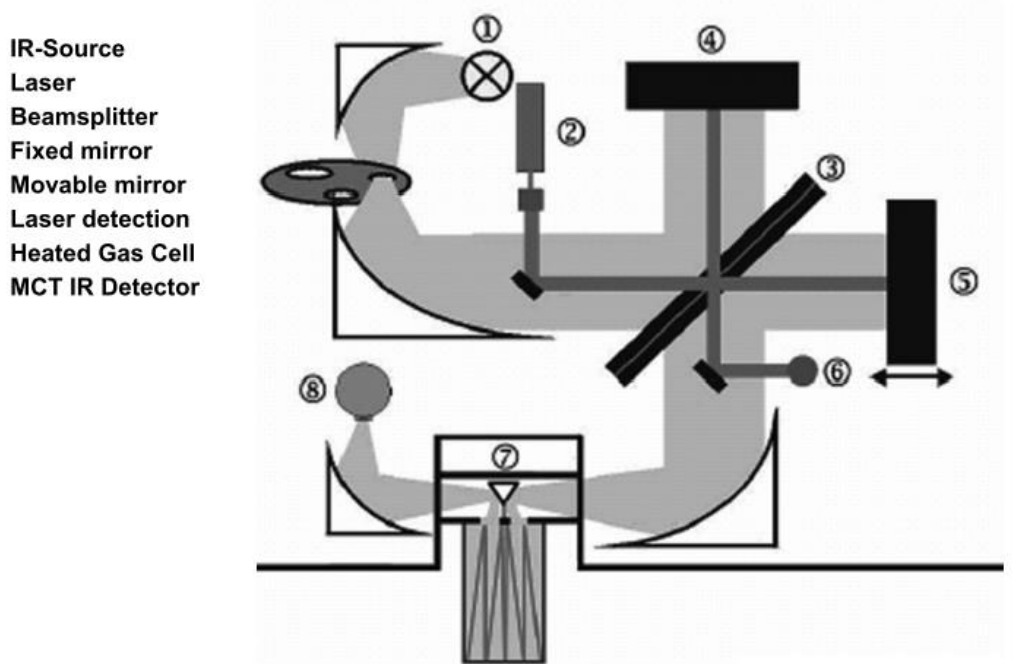

Figure 3. The spectrometer bench setup [11].

\subsubsection{Particulate Matter Measurement Method}

The AVL Micro soot sensor is based on the photoacoustic measurement method. With this measurement method, the sample gas with "black", i.e., strongly absorbing, soot particulates, is exposed to modulated light [14,15]. The periodical warming and cooling and the resulting expansion and contraction of the carrier gas can be regarded as a sound wave and detected utilizing microphones [16,17]. The principle of the photoacoustic measurement is shown in Figure 4.

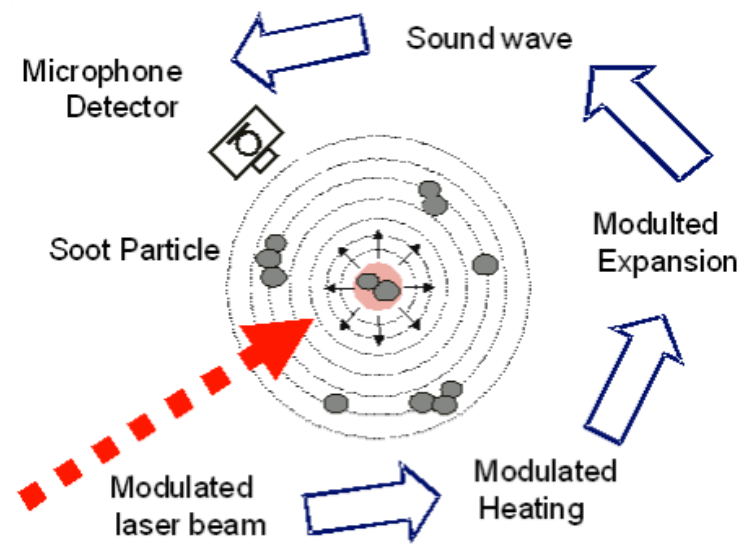

Figure 4. The principle of the photoacoustic measurement [12].

The diagram of the design of a resonant cell is shown in Figure 5. 


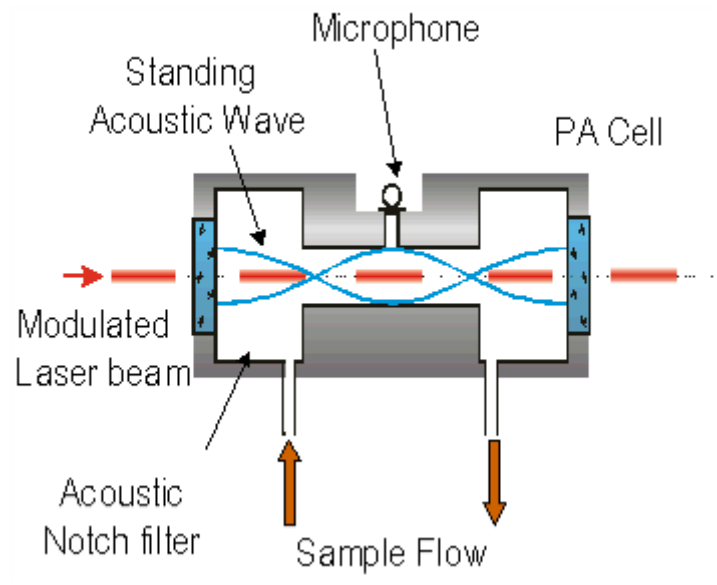

Figure 5. Design of a resonant cell [12].

\section{Examination of the Measured Data}

3.1. Engine Performance

The measured values are shown in Table 4 and visually displayed in Figure 6.

Table 4. Measured engine performance.

\begin{tabular}{|c|c|c|c|c|c|c|c|c|}
\hline \multicolumn{9}{|c|}{ Engine Performance } \\
\hline \multirow{2}{*}{$\begin{array}{l}\text { Engine } \\
\text { Speed }\end{array}$} & \multirow{2}{*}{$\begin{array}{c}\text { TPO } \\
\text { Concentration }\end{array}$} & \multirow{2}{*}{$\begin{array}{l}\text { Measured } \\
\text { Substance }\end{array}$} & \multicolumn{5}{|c|}{ Engine Load } & \multirow{2}{*}{ Color } \\
\hline & & & $40 \%$ & $50 \%$ & $60 \%$ & $80 \%$ & $100 \%$ & \\
\hline 1900 RPM & $0 \%$ & Torque (Nm) & 52.3 & 138.2 & 212.1 & 311.1 & 312.1 & \\
\hline 1900 RPM & $10 \%$ & Torque (Nm) & 43.7 & 131.7 & 203.0 & 307.1 & 307.6 & \\
\hline $2200 \mathrm{RPM}$ & $0 \%$ & Torque (Nm) & & & -51.7 & 145.0 & 286.0 & \\
\hline 2200 RPM & $10 \%$ & Torque (Nm) & & & -51.7 & 139.8 & 286.5 & \\
\hline $1900 \mathrm{RPM}$ & $0 \%$ & Power $(\mathrm{kW})$ & 10.4 & 27.5 & 42.2 & 61.9 & 62.1 & \\
\hline 1900 RPM & $10 \%$ & Power $(\mathrm{kW})$ & 8.7 & 26.2 & 40.4 & 61.1 & 61.2 & \\
\hline 2200 RPM & $0 \%$ & Power $(\mathrm{kW})$ & & & -11.9 & 33.4 & 65.9 & \\
\hline 2200 RPM & $10 \%$ & Power $(\mathrm{kW})$ & & & -11.9 & 32.2 & 66 & \\
\hline
\end{tabular}

\section{Power figures}

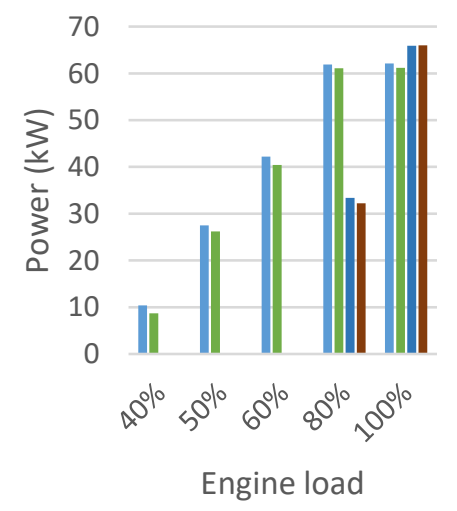

\section{Torque figures}

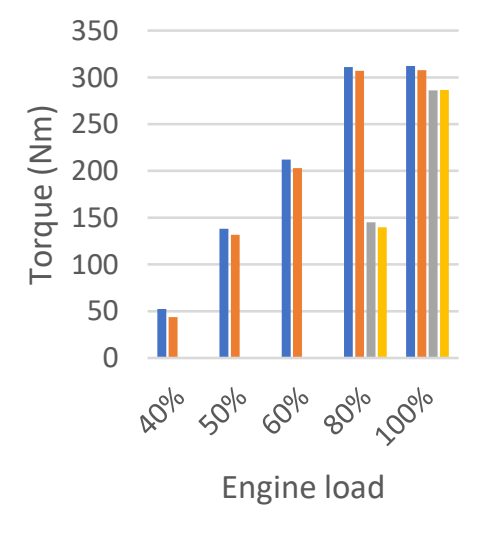

Figure 6. Torque and power curves of the engine.

At 1900 RPM with lower loads, minimal power loss can be seen, but as the load increases, minimal power loss can be seen, but the difference decreases as the load increases. This is most likely caused by the higher heating value of TPO. At 2200 RPM at full load, the 
engine made $0.5 \mathrm{Nm}$ more torque. In the table, negative values present an operatingpoint where the dynamometer rotated the engine.

\subsection{Fuel Consumption}

The measured values can be seen in Figure 7 and Table 5. Until full engine load, the brake-specific fuel consumption increased. With $40 \%$ load at 1900 RPM, the consumption was $10 \%$ higher with the TPO. With full load at 1900 RPM, the consumption equalized. Further increasing the engine speed favoured the TPO by further decreasing the consumption.

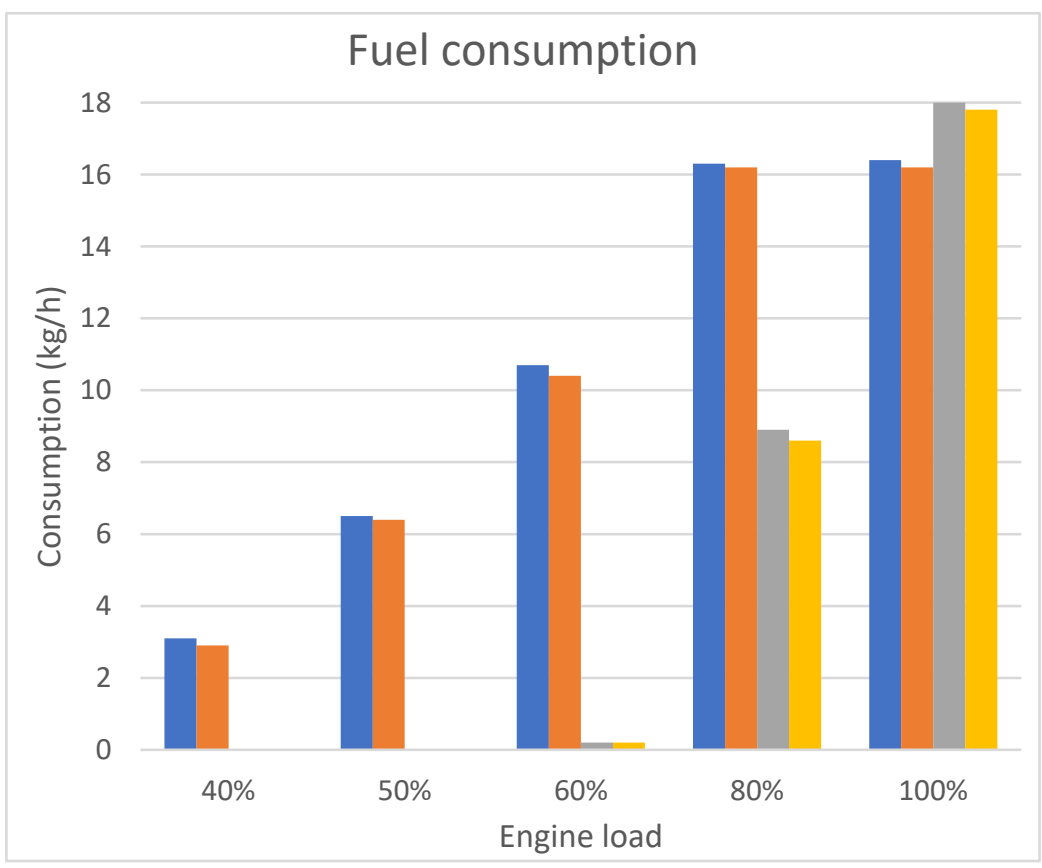

Figure 7. Fuel consumption of the engine.

Table 5. Measured fuel consumption values.

\begin{tabular}{ccccccc}
\hline \multicolumn{7}{c}{ Brake-Specific Fuel Consumption (g/kWh) } \\
\hline Engine & TPO & \multicolumn{5}{c}{ Engine Load } \\
\cline { 3 - 7 } Speed & Concentration & $\mathbf{4 0 \%}$ & $\mathbf{5 0 \%}$ & $\mathbf{6 0} \%$ & $\mathbf{8 0} \%$ & $\mathbf{1 0 0} \%$ \\
\hline 1900 RPM & $0 \%$ & 298.07 & 236.36 & 253.55 & 263.33 & 264.09 \\
1900 RPM & $10 \%$ & 333.33 & 244.27 & 257.42 & 265.14 & 264.71 \\
2200 RPM & $0 \%$ & & & & 266.47 & 273.14 \\
2200 RPM & $10 \%$ & & & & 267.08 & 269.70 \\
\hline
\end{tabular}

\subsection{Exhaust Emissions}

$\mathrm{CO}_{2}$ emssions are shown in Figure 8 and represented in Table 6.

Table 6. Measured $\mathrm{CO}_{2}$ values.

\begin{tabular}{ccccccc}
\hline & \multicolumn{7}{c}{ CO $_{\mathbf{2}}$ Emissions (PPM) } \\
\hline Engine & TPO & \multicolumn{5}{c}{ Engine Load } \\
\cline { 3 - 7 } Speed & Concentration & $\mathbf{4 0 \%}$ & $\mathbf{5 0 \%}$ & $\mathbf{6 0} \%$ & $\mathbf{8 0} \%$ & $\mathbf{1 0 0} \%$ \\
\hline 1900 RPM & $0 \%$ & 32,049 & 55,498 & 70,533 & 85,571 & 85,537 \\
1900 RPM & $10 \%$ & 29,938 & 56,343 & 72,183 & 87,284 & 87,020 \\
2200 RPM & $0 \%$ & & & 472 & 55,793 & 78,303 \\
2200 RPM & $10 \%$ & & 481 & 56,008 & 77,809 \\
\hline
\end{tabular}




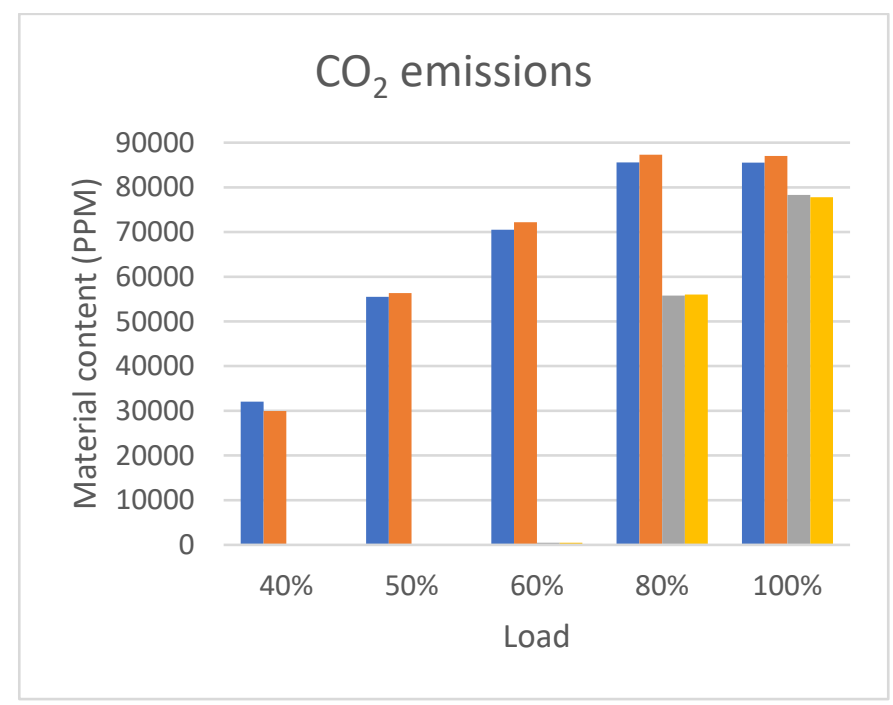

Figure 8. $\mathrm{CO}_{2}$ emissions of the engine.

At low loads, the pyrolysis diesel showed lower emission than regular diesel fuel, but as the loads became higher, the carbon dioxide emissions of the pyrolysis oil surpass the regular diesel's values. At 2200 RPM, the difference is minimal, and almost immeasurable.

The rest of the measured emissions are demonstrated in Figure 9 and Table 7.

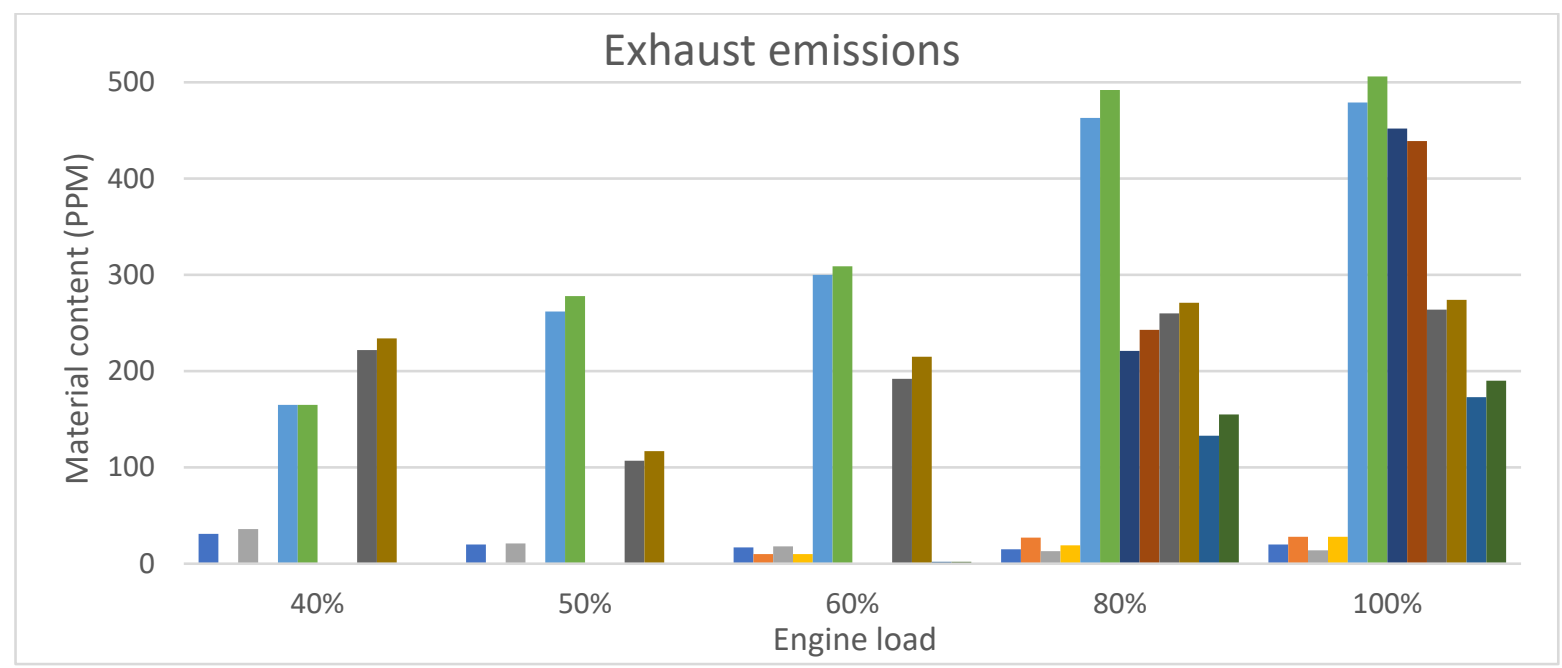

Figure 9. Different emissions of the engine.

Table 7. Measured emission values.

\begin{tabular}{|c|c|c|c|c|c|c|c|c|}
\hline \multicolumn{9}{|c|}{ Emission (PPM) } \\
\hline \multirow{2}{*}{$\begin{array}{l}\text { Engine } \\
\text { Speed }\end{array}$} & \multirow{2}{*}{$\begin{array}{c}\text { TPO } \\
\text { Concentration }\end{array}$} & \multirow{2}{*}{$\begin{array}{l}\text { Measured } \\
\text { Substance }\end{array}$} & \multicolumn{5}{|c|}{ Engine Load } & \multirow{2}{*}{ Color } \\
\hline & & & $40 \%$ & $50 \%$ & $60 \%$ & $80 \%$ & $100 \%$ & \\
\hline 1900 RPM & $0 \%$ & THC & 31 & 20 & 17 & 15 & 20 & \\
\hline 2200 RPM & $0 \%$ & THC & & & 10 & 27 & 28 & \\
\hline 1900 RPM & $10 \%$ & THC & 36 & 21 & 18 & 13 & 14 & \\
\hline 2200 RPM & $10 \%$ & THC & & & 10 & 19 & 28 & \\
\hline 1900 RPM & $0 \%$ & $\mathrm{NO}_{\mathrm{x}}$ & 165 & 262 & 300 & 463 & 479 & \\
\hline 1900 RPM & $10 \%$ & $\mathrm{NO}_{\mathrm{x}}$ & 165 & 278 & 309 & 492 & 506 & \\
\hline $2200 \mathrm{RPM}$ & $0 \%$ & $\mathrm{NO}_{\mathrm{x}}$ & & & 0 & 221 & 452 & \\
\hline $2200 \mathrm{RPM}$ & $10 \%$ & $\mathrm{NO}_{\mathrm{x}}$ & & & 0 & 243 & 439 & \\
\hline 1900 RPM & $0 \%$ & $\mathrm{CO}$ & 222 & 107 & 192 & 260 & 264 & \\
\hline $1900 \mathrm{RPM}$ & $10 \%$ & $\mathrm{CO}$ & 234 & 117 & 215 & 271 & 274 & \\
\hline $2200 \mathrm{RPM}$ & $0 \%$ & $\mathrm{CO}$ & & & 2 & 133 & 173 & \\
\hline 2200 RPM & $10 \%$ & $\mathrm{CO}$ & & & 2 & 155 & 190 & \\
\hline
\end{tabular}


The HC emissions showed various results. At low speed and low load, the TPO had a $16 \%$ higher emission value. With the increased engine loads, the HC emissions decreased and, at $100 \%$ load, it was $42 \%$ lower than regular diesels. The $\mathrm{NO}_{\mathrm{x}}$ emissions increased overall, except for the maximum load at 2200 RPM. The reason for that might be the lack of oxygen at the measuring point. $\mathrm{CO}$ emissions showed an increase in all investigated measuring points. The values roughly increased by $10 \%$ overall.

\subsection{Data Validity for General Use}

The data obtained shows a general trend about how the TPO affects the engine performance and exhaust emissions. Using modern catalytic converters and other after treatment devices, the values could be further optimized, thus making the TPO a good alternative for biofuels.

\section{Conclusions}

The engine's power output and torque decreased minimally, but the brake-specific fuel consumption also showed lower values with it. During the experiments, the fuel supply and the fuel injection system did not show any signs of failure. The engine did not have any exhaust treatment device attached to it. The measured values only differ minimally, and with proper treatment; thus, this could be further improved.

Author Contributions: I.P.K. and D.M. conducted the tests on the injector testbench and I.P.K. wrote the publication. M.Z. developed the simulations and supervised the paper. All authors have read and agreed to the published version of the manuscript.

Funding: This research was funded by KTI grant number KTI_KVIG_8-1_2021 and the APC was funded by KTI_KVIG_8-1_2021.

Acknowledgments: The research reported in this paper and carried out at BME has been supported by the KTI_KVIG_8-1_2021 fund based on the charter of bolster issued by the KTI.

Conflicts of Interest: The authors declare no conflict of interest.

\section{Nomenclature}

AVL Anstalt für Verbrennungskraftmaschinen List

$\mathrm{CO}$ Carbon monoxide

$\mathrm{CO}_{2} \quad$ Carbon dioxide

FTIR Fourier-transform infrared

HC Hydrogen carbon

IR Infrared

ISO International Organization for Standardization

KW Kilowatt

MSS Micro soot sensor

MSZ Hungarian standard

$\mathrm{NO}_{\mathrm{x}} \quad$ Nitrogen dioxide

MCT Mercury cadmium telluride

NDIR Nondispersive infrared sensor

NM Newton meter

PM Particulate matter

PPM Parts per million

RPM Revolution per minute

PUMA Prüf und Mess Automatisierung

THC Total hydrocarbons

TPO Tire pyrolysis Oil 


\section{References}

1. Kordoghli, S.; Paraschiv, M.; Kuncser, R.; Tazerout, M.; Prisecaru, M.; Zagrouba, F.; Georgescu, I. Managing the environmental hazards of the waste tires. J. Eng. Des. 2014, 20, 1466-1837. [CrossRef]

2. Martínez, J.D.; Puy, N.; Murillo, R.; García, T.; Navarro, M.V.; Mastral, A.M. Waste tyre pyrolysis-A review. Renew. Sustain. Energy Rev. 2013, 23, 179-213. [CrossRef]

3. Zöldy, M. Investigation of Correlation Between Diesel Fuel Cold Operability and Standardised Cold Flow Properties. Period. Polytech. Transp. Eng. 2021, 49, 120-125. [CrossRef]

4. Ramalingam, K.; Balasubramanian, D.; Chellakumar, P.J.T.J.S.; Padmanaban, J.; Murugesan, P.; Xuan, T. An assessment on production and engine characterization of a novel environment-friendly fuel. Fuel 2020, 279, 118558. [CrossRef]

5. Zöldy, M. The Changes of Burning Efficiency Emission and Power Output of a Diesel Engine Fueled by Bioethanol-Biodiesel-Diesel Oil Mixtures; FISITA: Yokohama, Japan, 2006.

6. Valeika, G.; Matijošius, J.; Górski, K.; Rimkus, A.; Smigins, R. A Study of Energy and Environmental Parameters of a Diesel Engine Running on Hydrogenated Vegetable Oil (HVO) with Addition of Biobutanol and Castor Oil. Energies 2021, $14,3939$. [CrossRef]

7. Zöldy, M.; Kondor, I.P. Simulation and Injector Bench Test Validation of Different Nozzle Hole Effect on Pyrolysis Oil-Diesel Oil Mixtures. Energies 2021, 14, 2396. [CrossRef]

8. Vass, S.; Zöldy, M. Detailed model of a common rail injector. Acta Univ. Sapientiae Electr. Mech. Eng. 2019, 11, 22-33. [CrossRef]

9. Baškovič, U.Ž.; Seljak, T.; Katrašnik, T. Feasibility analysis of 100\% tire pyrolysis oil in a common rail Diesel engine. Energy 2017, 137, 980-990. [CrossRef]

10. Pejić, G.; Bijelić, F.; Zovak, G.; Lulić, Z. Model for Calculating Average Vehicle Mileage for Different Vehicle Classes Based on Real Data: A Case Study of Croatia. Promet-Traffic Transp. 2019, 31, 213-222. [CrossRef]

11. AVL SESAM i60 Fourier-Transform Infrared Spectrometer Measurement Device User Manual. Available online: https: / / www.avl.com/testing-solutions-for-large-engines/- / asset_publisher/gYjUpY19vEA8/content/avl-sesam-i60-ft-multicomponent-exhaust-measurement-system (accessed on 9 November 2021).

12. AVL MSS Micro Soot Sensor Measurement Device User Manual. Available online: https://www.avl.com/-/mssplus-avl-microsoot-sensor (accessed on 9 November 2021).

13. Rimkus, A.; Matijošius, J.; Bogdevičius, M.; Bereczky, Á.; Török, Á. An investigation of the efficiency of using $\mathrm{O}_{2}$ and $\mathrm{H}_{2}$ (hydrooxile gas-HHO) gas additives in a ci engine operating on diesel fuel and biodiesel. Energy 2018, 152, 640-651. [CrossRef]

14. Kirchen, P.; Obrecht, P.; Boulouchos, K. Soot Emission Measurements and Validation of a Mean Value Soot Model for Common-Rail Diesel Engines during Transient Operation. SAE Int. J. Engines 2009, 2, 1663-1678. [CrossRef]

15. Kirchen, P.; Obrecht, P.; Boulouchos, K.; Bertola, A. Exhaust-Stream and In-Cylinder Measurements and Analysis of the Soot Emissions From a Common Rail Diesel Engine Using Two Fuels. J. Eng. Gas Turbines Power 2010, 132, 112804. [CrossRef]

16. Breitegger, P.; Schriefl, M.A.; Nishida, R.T.; Hochgreb, S.; Bergmann, A. Soot mass concentration sensor using quartz-enhanced photoacoustic spectroscopy. Aerosol Sci. Technol. 2019, 53, 971-975. [CrossRef]

17. Kontses, D.; Geivanidis, S.; Fragkiadoulakis, P.; Samaras, Z. Uncertainties in Model-Based Diesel Particulate Filter Diagnostics Using a Soot Sensor. Sensors 2019, 19, 3141. [CrossRef] [PubMed] 